\begin{tabular}{|c|c|c|}
\hline & Int.J.Curr.Microbiol.App.Sci (2021) 10(08): 312-319 & \\
\hline & $\begin{array}{l}\text { International Journal of Current Micro6iology and Applied Sciences } \\
\text { ISSN: 2319-7706 Volume } \mathbf{1 0} \text { Number } \mathbf{0 8}(\mathbf{2 0 2 1}) \\
\text { Journal homepage: http://www.ijcmas.com }\end{array}$ & $\begin{array}{l}50 \\
502\end{array}$ \\
\hline $\begin{array}{l}\text { EXCELLENT } \\
\text { PUBLISHERS }\end{array}$ & & whwe.jicmascom \\
\hline
\end{tabular}

Original Research Article

https://doi.org/10.20546/ijcmas.2021.1008.036

\title{
Effect of Sulphur Levels and FYM on Yield, Oil Content and Nutrient Uptake of Safflower under Dry Land Agriculture
}

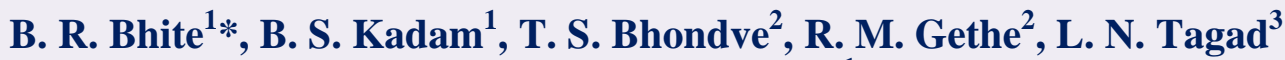 \\ and V. M. Amrutsagar ${ }^{1}$ \\ ${ }^{I} N A R P$ for Dryland Agriculture, \\ ${ }^{2}$ AICRP DLA, \\ ${ }^{3}$ AICRP on Safflower, Zonal Agriculture Research Station Solapur, Maharashtra, India \\ *Corresponding author
}

Keywords

Safflower, Sulphur, palmitic acid, linolic acid, oleic acid

\section{Article Info}

Accepted:

15 July 2021

Available Online:

10 August 2021

\section{A B S T R A C T}

The Field experiments were conducted during the six consecutive years (kharif) from 2013-14 to 2019-20 at the Dryland Farming Research Station, Zonal Agriculture Research Station, Solapur to ascertain the effect of sulphur levels and FYM on yield, oil content and nutrient uptake of safflower under dry land agriculture. Application of NPK 50:25:00 kg ha-1 + FYM $1 \mathrm{t} \mathrm{ha}^{-1}$ with sulphur $40 \mathrm{~kg} \mathrm{ha}^{-1}$ recorded significantly higher plant height $(78.70 \mathrm{~cm})$, number of capsules / plant (22.58), 100 grain weight $(6.55 \mathrm{gm})$, moisture use efficiency for grain $\left(6.30 \mathrm{~kg} \mathrm{ha}^{-1} \mathrm{~mm}^{-1}\right)$, grain and straw yield (15.83 and $38.42 \mathrm{q} \mathrm{ha}^{-1}$ ) oil yield $\left(500.3 \mathrm{~kg} \mathrm{ha}^{-1}\right)$, oil content $(31.60 \%)$ significantly higher uptake of $\mathrm{N}, \mathrm{P}$ and $\mathrm{K}(44.76,17.37$ and $100.15 \mathrm{~kg} \mathrm{ha}^{-1}$ ) with higher gross monitory returns, net returns and cost benefit ratio (Rs.72249/-,Rs.47429/- and 2.91).

\section{Introduction}

In India, safflower (Carthamus tinctorius L.) is the crucial annual oilseed crop grown in rabi season and occupies 0.46 lakh ha. with productivity of $537 \mathrm{~kg} \mathrm{ha}^{-1}$ while in Maharashtra it grown on 0.25 lakh ha with productivity of $475 \mathrm{~kg} \mathrm{ha}^{-1}$ in the year 201819. Seed contains 30-40\% oil and 15-20\% protein (Rahamatalla et al., 2001) and mostly possess fatty acid like stearic acid (2-3\%), oleic acid (16-20\%), palmitic acid (6-8\%) and linolic acid (71-75\%). It is the most suitable crop for the dryland farming due to its important characteristics like drought resistance, deep root system, short duration, cultivable in all types of soil with low inputs and grown on residual soil moisture (Walia et al., 2005). Most of the world oilseed production occurs in the semi arid tropics 
suffer from sulphur deficiency resulting in low yield. Sulphur fertilization influences the composition of the oil. Sulphur fertilization with an adequate supply of nitrogen and phosphorous accelerate the metabolic pathway of linolenic acid synthesis as it result in a large decrease in the percentage of stearic acid, oleic and linoleic acid with concurrent increase in the content of linolenic acid (Nagaraj, 1993). The oil is rich in polyunsaturated fatty acid and is beneficial to the patients having cardiac problems. FYM is a store house of several macro and micronutrients which are released during the process of mineralization and stimulated the activity of microorganism that make the plant nutrients readily available to the crop (Rasool et. al. 2013).

Sulphur ranks $13^{\text {th }}$ in terms of abundance in the earth's crust and is the fourth major plant nutrient after $\mathrm{N}, \mathrm{P}$ and $\mathrm{K}$ (Kanwar and Mudahar, 1986). Mineralization of organic matter releases sulphur in the available form to the plant and plant absorb sulphur mostly through roots in the form of sulphate (Singh et. al. 2001). Sulphur helps in increasing the oil content of oil seed crops and acts as a major nutrient in determining the quality of oil (Roy and Ghosh, 2020). Sulphur helps in the synthesis of cystein, methionine, chlorophyll, vitamins (Biotin and thiamin), metabolism of carbohydrates especially by its effect on the protolytic enzymes (Najar et al., 2011).

In the recent year, a concept of integrated nutrient supply involving the use of organic manures and inorganic fertilizers has been developed to obtain sustained agriculture production (Gaikwad and Puranik, 1996.) Integrated nutrient management (INM) involves the use of manures, biofertilizers and chemical fertilizers to achieve sustained crop production and maintain better soil health. INM is better approach for better utilization of resources and to produce crops with less expenditure. In view of these, the present investigation was carried out to study the effect of sulphur levels and FYM on yield, oil content and nutrient uptake of safflower under dryland condition.

\section{Materials and Methods}

The field experiment was conducted on the Dryland Farming Research Station, Zonal Agriculture Research Station, Solapur for the six consecutive years (kharif) from 2013-14 to 2019-20. The experiment was laid out in Randomized Block Design, having seven treatments combinations which were replicated four times and compared with the recommended dose. The treatments are $\mathrm{T}_{1}$ i.e. Absolute control, $\mathrm{T}_{2}$ i.e. (R.D.F. $\mathrm{N}: \mathrm{P}_{2} \mathrm{O}_{5}$ : $\mathrm{K}_{2} \mathrm{O}: 50: 25: 0 \mathrm{~kg} \mathrm{ha}^{-1}+\mathrm{FYM} 1 \mathrm{t} \mathrm{ha}^{-1)}, \mathrm{T}_{3}$ i.e. R.D.F + FYM $1 \mathrm{t} \mathrm{ha}^{-1}+$ sulphur $10 \mathrm{~kg} \mathrm{ha}^{-1,} \mathrm{~T}_{4}$ i.e. R.D.F + FYM $1 \mathrm{t} \mathrm{ha}^{-1}+$ sulphur $20 \mathrm{~kg} \mathrm{ha}^{-1}$, $\mathrm{T}_{5}$ i.e. R.D.F + FYM $1 \mathrm{t} \mathrm{ha}^{-1}+$ sulphur $30 \mathrm{~kg}$ ha $^{-1,} \mathrm{~T}_{6}$ i.e. R.D.F + FYM $1 \mathrm{t} \mathrm{ha}^{-1}+$ sulphur 40 $\mathrm{kg} \mathrm{ha}^{-1}$ and $\mathrm{T}_{7}$ i.e. R.D.F + FYM $1 \mathrm{t} \mathrm{ha}^{-1}+$ sulphur $50 \mathrm{~kg} \mathrm{ha}^{-1}$. FYM as per the treatment was incorporated in the soil and the $\mathrm{N}$ and $\mathrm{P}$ was uniformly applied to each plot as a basal dose during both the years of the experiment. Sulphur was applied through elemental sulphur. The seeds of safflower variety SSF708 was line sown spaced at 45×20 cm. Five random plants were selected in each treatment excluding the border row for taking the observations of plant height, No. of capsules / plant and 100 grain weight. Soil $\mathrm{P}^{\mathrm{H}}$ was measured in 1:2 soil water suspensions where $10 \mathrm{gm}$ of soil was taken and stirred intermittently for 30 minutes with $20 \mathrm{ml}$ of water and measured with $\mathrm{P}^{\mathrm{H}}$ meter (McLean, 1982). The electrical conductivity was measured in 1:2 soil water suspensions using conductivity meter (Rhoades, 1982). N.P and $\mathrm{K}$ content of crop residues were analyzed by standard procedures outline by Jackson (1973).Organic carbon (Walkley and Black, 1934). Available N (Subbaiah and Asija, 
1956), Available $\mathrm{P}_{2} \mathrm{O}_{5}$ (Olsen et al., 1954) and Available $\mathrm{K}_{2} \mathrm{O}$ (Knudsen and Peterson, 1982). Sulpher (Singh et al.,1988). The oil content in the seeds for each treatment was determined by Nuclear Magnetic Resonance analysis (Tiwari et al., 1974). The data obtained in respect of the observations was statistically analyzed by Pance and Sukhatme (1985).

\section{Results and Discussion}

\section{Morphological Characters and MUE}

The pooled data of effect of sulphur levels and FYM on MUE and morphological characters i.e. plant height, No. of capsules / plant and 100 grain weight was presented in Table 1. The data depicted in the table showed that, the higher moisture use efficiency for grain (6.30 $\mathrm{kg} \mathrm{ha}^{-1} \mathrm{~mm}^{-1)}$ was recorded in treatment $\mathrm{T}_{6}$ i.e. NPK 50:25:00 kg ha ${ }^{-1}$ FYM $1 \mathrm{t} \mathrm{ha}^{-1}$ with sulphur $40 \mathrm{~kg} \mathrm{ha}^{-1}$ followed by $\mathrm{T}_{7}\left(5.78 \mathrm{~kg} \mathrm{ha}^{-}\right.$ ${ }^{1} \mathrm{~mm}^{-1}$ ).

As regards to the morphological characters, Treatment $\mathrm{T}_{6}$ i.e. NPK 50:25:00 kg ha ${ }^{-1}+$ FYM 1 tha $^{-1}$ with sulphur $40 \mathrm{~kg} \mathrm{ha}^{-1}$ recorded significantly higher plant height, number of capsules and 100 grain weight $(78.70 \mathrm{~cm}$, 22.58 no of capsules / plant and $6.55 \mathrm{gm}$ respectively) over rest of the treatments.

Increased in plant height might be due to increased in metabolic processes in the plant and increased meristamatic activities causing more apical growth. Synthesis of proteins due to sulphur may have resulted in proper partitioning of photosynthesis from source to sink resulting in improvement in yield contributing attributes like 100 grain weight. Rasool et al., (2013) reported that, synthesis of phytin (Isoinsitolhexa phosphate) which is a salt of $\mathrm{Ca}$, magnesium $(\mathrm{Mg}$ ) and $\mathrm{P}$ (salt of $\mathrm{Ca}$ and $\mathrm{Mg}$ are present in cow urine) may have increased the seed weight.

\section{Grain, Straw, oil yield and oil content}

The pooled data of effect of sulphur levels and FYM on Grain, Straw, oil yield and oil conten of safflower under dryland agriculture as influenced by different treatments were presented in Table 2. From this table, it was revealed that, the treatment $\mathrm{T}_{6}$ i.e. NPK 50:25:00 kg ha ${ }^{-1}+$ FYM $1 \mathrm{t} \mathrm{ha}^{-1}$ with sulphur40 $\mathrm{kg} \mathrm{ha}{ }^{-1}$ recorded significantly higher grain, straw, oil yield and oil content (15.83 and $38.42 \mathrm{q} \mathrm{ha}^{-1}, 500.3 \mathrm{~kg} \mathrm{ha}^{-1}$ and $31.60 \%$ ) over rest of the treatments. Whereas, treatment $\mathrm{T}_{1}$ i.e. absolute control recorded lowest grain, straw, oil yield and oil content (7.97 and $17.24 \mathrm{q} \mathrm{ha}^{-1}, 240.7 \mathrm{~kg} \mathrm{ha}^{-1}$ and 30.22 $\%)$. Increased in yield to be associated with release of nutrients during microbial decomposition. Organic matter is a source of energy for soil microflora which brings transformation of inorganic nutrients held in soil in a form that readily utilized by growing plants. FYM help in increasing the availability of sufficient amount of nutrients throughout growth period resulting in better uptake, plant vigour and superior yield attributes (Shivakumar and Ahlawat, 2008). Kumar et al., (2009) reported that, use of organic manures along with inorganic fertilizers attribute to higher availability and adsorption of nutrients. Thirumelai and Khalak (1993) reported that, increase in stover yield in soybean might be due to supply of essential mineral nutrients in balanced amount which resulted in better growth and development of plants. 
Table.1 Effect of sulphur levels and FYM on growth, yield contributing character and MUE of safflower (pooled mean of 2013-14 to 2019-20 )

\begin{tabular}{|c|c|c|c|c|}
\hline Treatments & $\begin{array}{c}\text { Plant } \\
\text { Height } \\
\text { (cm) }\end{array}$ & $\begin{array}{c}\text { No. of } \\
\text { capsules / } \\
\text { plant }\end{array}$ & $\begin{array}{l}100 \text { grain } \\
\text { wt. (gm) }\end{array}$ & $\begin{array}{c}\text { MUE } \\
\left(\mathrm{kg} \mathrm{ha}^{-1}\right. \\
\left.\text { mm }^{-1}\right)\end{array}$ \\
\hline $\mathbf{T}_{1 . \text { Absolute Control }}$ & 70.52 & 12.58 & 5.85 & 3.22 \\
\hline $\mathrm{T}_{2 .}$ RDF N:P $\mathrm{P}_{2} \mathrm{O}_{5}(50: 25: 0)+\mathrm{FYM} 1 \mathrm{tha}^{-1}$ & 72.87 & 16.77 & 6.15 & 4.45 \\
\hline $\begin{array}{l}\text { T. RDF + FYM } 1 \text { tha }^{-1}+\text { Sulphur } 10 \\
\text { kgha }^{-1}\end{array}$ & 72.48 & 18.68 & 6.25 & 4.86 \\
\hline $\begin{array}{l}\text { T4. RDF + FYM } 1 \text { tha }^{-1}+\text { Sulphur } 20 \\
\text { kgha }^{-1}\end{array}$ & 74.65 & 19.53 & 6.37 & 4.89 \\
\hline $\begin{array}{l}\text { T5. RDF + FYM } 1 \text { tha }^{-1}+\text { Sulphur } 30 \\
\text { kgha }^{-1}\end{array}$ & 75.50 & 20.85 & 6.54 & 5.35 \\
\hline $\begin{array}{l}\text { T6. RDF + FYM } 1 \text { tha }^{-1}+\text { Sulphur 40kg } \\
\text { ha }^{-1}\end{array}$ & 78.70 & 22.58 & 6.55 & 6.30 \\
\hline $\begin{array}{l}\text { T. RDF + FYM } 1 \text { tha }^{-1}+\text { Sulphur } 50 \\
\text { kgha }^{-1}\end{array}$ & 74.48 & 20.57 & 6.37 & 5.78 \\
\hline SE \pm & 0.99 & 0.64 & 0.09 & 0.34 \\
\hline CD at $5 \%$ & 2.89 & 1.86 & 0.28 & 0.97 \\
\hline
\end{tabular}

Table.2 Effect of sulphur levels and FYM on yield and quality parameters of safflower (pooled mean of 2013-14 to 2019-20 )

\begin{tabular}{|c|c|c|c|c|}
\hline Treatments & $\begin{array}{c}\text { Grain } \\
\text { yield } \\
\left(\mathbf{q} \mathbf{h a}^{-1}\right)\end{array}$ & $\begin{array}{c}\text { Stover } \\
\text { yield } \\
\left(\mathbf{q} \mathbf{h a}^{-1}\right)\end{array}$ & $\begin{array}{l}\text { Oil yield } \\
\left(\mathrm{kg} \mathrm{ha}^{-1}\right)\end{array}$ & $\begin{array}{c}\text { Oil } \\
\text { content } \\
(\%)\end{array}$ \\
\hline $\mathbf{T}_{1}$. Absolute Control & 7.97 & 17.24 & 240.7 & 30.22 \\
\hline $\mathrm{T}_{2 .}$ RDF N:P $\mathrm{P}_{5}(50: 25: 0)+$ FYM $1 \mathrm{tha}^{-1}$ & 10.29 & 23.11 & 314.4 & 30.56 \\
\hline T $_{3 .}$ RDF + FYM 1 tha $^{-1}+$ Sulphur 10 kgha $^{-1}$ & 11.75 & 27.50 & 364.1 & 31.00 \\
\hline $\mathrm{T}_{4 .}$ RDF + FYM 1 tha $^{-1}+$ Sulphur $20 \mathrm{kgha}^{-1}$ & 12.98 & 31.15 & 405.1 & 31.21 \\
\hline T $_{5 .}$ RDF + FYM 1 tha $^{-1}+$ Sulphur 30 kgha $^{-1}$ & 13.90 & 33.08 & 437.1 & 31.46 \\
\hline T $_{6 .}$ RDF + FYM 1 tha $^{-1}+$ Sulphur 40kg ha ${ }^{-1}$ & 15.83 & 38.42 & 500.3 & 31.60 \\
\hline T $_{7 .}$ RDF + FYM 1 tha $^{-1}+$ Sulphur $50 \mathrm{kgha}^{-1}$ & 14.31 & 34.66 & 449.8 & 31.43 \\
\hline $\mathrm{SE} \pm$ & 0.31 & 0.91 & 9.78 & 0.07 \\
\hline CD at $5 \%$ & 0.89 & 2.63 & 28.39 & 0.20 \\
\hline
\end{tabular}


Table.3 Effect of sulphur levels and FYM on Nutrient uptake of safflower (pooled mean of 2013-14 to 2019-20)

\begin{tabular}{|c|c|c|c|}
\hline Treatments & $\begin{array}{c}\text { N uptake } \\
\left(\text { kgha }^{-1}\right)\end{array}$ & $\begin{array}{l}\text { P uptake } \\
\left(\text { kgha }^{-1}\right)\end{array}$ & $\begin{array}{c}\text { K uptake } \\
\left(\text { kgha }^{-1}\right)\end{array}$ \\
\hline $\mathbf{T}_{1}$. Absolute Control & 24.01 & 7.50 & 47.84 \\
\hline $\mathrm{T}_{2 .}$ RDF N:P $\mathrm{P}_{2}(50: 25: 0)+$ FYM $1 \mathrm{t} \mathrm{ha}^{-1}$ & 29.15 & 9.47 & 62.07 \\
\hline$T_{3 .}$ RDF + FYM 1 tha $^{-1}+$ Sulphur $10 \mathrm{kgha}^{-1}$ & 33.77 & 10.70 & 72.07 \\
\hline T $_{4 .}$ RDF + FYM 1 tha $^{-1}+$ Sulphur 20 kgha $^{-1}$ & 35.63 & 13.29 & 80.53 \\
\hline$T_{5 .}$ RDF + FYM 1 tha $^{-1}+$ Sulphur $30 \mathrm{kgha}^{-1}$ & 37.94 & 15.15 & 86.63 \\
\hline$T_{6 .}$ RDF + FYM 1 tha $^{-1}+$ Sulphur 40kg ha ${ }^{-1}$ & 44.76 & 17.37 & 100.15 \\
\hline T. $_{7 .}$ RDF + FYM 1 tha $^{-1}+$ Sulphur 50 kgha $^{-1}$ & 39.18 & 15.43 & 90.60 \\
\hline $\mathrm{SE}_{ \pm}$ & 1.01 & 0.61 & 2.48 \\
\hline CD at $5 \%$ & 2.97 & 1.79 & 7.28 \\
\hline
\end{tabular}

Table.4 Effect of sulphur levels and FYM on Soil properties (pooled mean of 2013-14 to 2019-20)

\begin{tabular}{|c|c|c|c|c|}
\hline Treatments & pH & $\begin{array}{c}\mathrm{EC} \\
\left(\mathrm{dSm}^{-1}\right)\end{array}$ & $\begin{array}{c}\text { Organic } \\
\text { Carbon } \\
(\%)\end{array}$ & $\begin{array}{l}\text { Sulphur } \\
\text { content } \\
\text { (ppm) }\end{array}$ \\
\hline $\mathbf{T}_{1}$. Absolute Control & 7.57 & 0.30 & 0.40 & 5.33 \\
\hline $\mathrm{T}_{2 .}$ RDF N:P $\mathrm{O}_{5}(50: 25: 0)+\mathrm{FYM} 1 \mathrm{t} \mathrm{ha} \mathrm{i}^{-1}$ & 7.69 & 0.31 & 0.45 & 5.91 \\
\hline$T_{3 .}$ RDF + FYM 1 tha $^{-1}+$ Sulphur 10 kgha $^{-1}$ & 7.62 & 0.33 & 0.46 & 6.60 \\
\hline $\mathrm{T}_{4 .}$ RDF + FYM 1 tha $^{-1}+$ Sulphur $20 \mathrm{kgha}^{-1}$ & 7.60 & 0.33 & 0.48 & 7.54 \\
\hline $\mathrm{T}_{5 .}$ RDF + FYM 1 tha $^{-1}+$ Sulphur $30 \mathrm{kgha}^{-1}$ & 7.63 & 0.31 & 0.46 & 8.16 \\
\hline T $_{6 .}$ RDF + FYM 1 tha $^{-1}+$ Sulphur $40 \mathrm{~kg} \mathrm{ha}^{-1}$ & 7.55 & 0.32 & 0.48 & 9.40 \\
\hline T $_{7 .}$ RDF + FYM 1 tha $^{-1}+$ Sulphur 50 kgha $^{-1}$ & 7.60 & 0.31 & 0.50 & 9.62 \\
\hline $\mathrm{SE}_{ \pm}$ & 0.04 & 0.014 & 0.02 & 0.19 \\
\hline CD at $5 \%$ & NS & NS & NS & 0.55 \\
\hline
\end{tabular}

Table.5 Effect of sulphur levels and FYM on Nutrient availability (pooled mean of 2013-14 to 2019-20)

\begin{tabular}{|c|c|c|c|}
\hline Treatments & $\begin{array}{c}\text { Available } \\
\mathbf{N} \\
\left(\text { kgha }^{-1}\right)\end{array}$ & $\begin{array}{c}\text { Available } \\
\text { P } \\
\left(\text { kgha }^{-1}\right)\end{array}$ & $\begin{array}{c}\text { Available } \\
\text { K } \\
\left(\mathrm{kgha}^{-1}\right)\end{array}$ \\
\hline $\mathbf{T}_{1}$. Absolute Control & 144.8 & 9.56 & 552.5 \\
\hline $\mathrm{T}_{2 .}$ RDF N:P $\mathrm{P}_{2} \mathrm{O}_{5}(50: 25: 0)+$ FYM $1 \mathrm{tha}^{-1}$ & 163.2 & 13.41 & 590.8 \\
\hline $\mathrm{T}_{3 .}$ RDF + FYM 1 tha $^{-1}+$ Sulphur 10 kgha $^{-1}$ & 167.8 & 14.06 & 594.7 \\
\hline T $_{4 .}$ RDF + FYM 1 tha $^{-1}+$ Sulphur 20 kgha $^{-1}$ & 171.8 & 14.08 & 611.8 \\
\hline T $_{5 .}$ RDF + FYM 1 tha $^{-1}+$ Sulphur 30 kgha $^{-1}$ & 173.2 & 14.71 & 611.7 \\
\hline T $_{6 .}$ RDF + FYM 1 tha $^{-1}+$ Sulphur 40kg ha ${ }^{-1}$ & 176.0 & 15.16 & 624.0 \\
\hline T $_{7 .}$ RDF + FYM 1 tha $^{-1}+$ Sulphur $50 \mathrm{kgha}^{-1}$ & 174.2 & 15.15 & 614.7 \\
\hline $\mathrm{SE} \pm$ & 5.03 & 0.39 & 8.22 \\
\hline CD at $5 \%$ & 14.59 & 1.21 & 23.84 \\
\hline
\end{tabular}


Table.6 Effect of sulphur levels and FYM on economics of safflower under dryland Agriculture (pooled mean of 2013-14 to 2019-20)

\begin{tabular}{|c|c|c|c|c|c|c|c|}
\hline \multirow{2}{*}{$\begin{array}{l}\text { Tr. } \\
\text { No. }\end{array}$} & \multirow[t]{2}{*}{ Treatment details } & \multicolumn{2}{|c|}{ Yield (q ha-1) } & \multirow{2}{*}{$\begin{array}{l}\text { Cost of } \\
\text { cultivation } \\
\left(\operatorname{Rs~ha}^{-1}\right)\end{array}$} & \multirow{2}{*}{$\begin{array}{c}\text { Gross } \\
\text { Monetary } \\
\text { returns } \\
\left(\text { Rs ha }^{-1}\right)\end{array}$} & \multirow{2}{*}{$\begin{array}{c}\text { Net } \\
\text { returns } \\
\left(\operatorname{Rs~ha}^{-1}\right)\end{array}$} & \multirow{2}{*}{$\begin{array}{l}\mathrm{B}: \mathrm{C} \\
\text { ratio }\end{array}$} \\
\hline & & Grain & Stover & & & & \\
\hline $\mathbf{T}_{1}$ & Absolute Control & 7.97 & 17.24 & 16500 & 36060 & 19560 & 2.19 \\
\hline $\mathbf{T}_{2}$ & $\begin{array}{c}\mathrm{RDF} \mathrm{N}: \mathrm{P}_{2} \mathrm{O}_{5} \\
(50: 25: 0)+\mathrm{FYM} 1 \\
\mathrm{t} \mathrm{ha}^{-1}\end{array}$ & 10.29 & 23.11 & 23200 & 46684 & 23484 & 2.01 \\
\hline $\mathbf{T}_{\mathbf{3}}$ & $\begin{array}{l}\text { RDF + FYM } 1 \text { tha }^{-1} \\
+ \text { Sulphur } 10 \mathrm{kgha}^{-1}\end{array}$ & 11.75 & 27.50 & 23620 & 53475 & 29855 & 2.26 \\
\hline $\mathbf{T}_{4}$ & $\begin{array}{l}\text { RDF + FYM } 1 \text { tha }^{-1} \\
+ \text { Sulphur } 20 \mathrm{kgha}^{-1}\end{array}$ & 12.98 & 31.15 & 24020 & 59188 & 35168 & 2.46 \\
\hline $\mathbf{T}_{5}$ & $\begin{array}{l}\text { RDF + FYM } 1 \text { tha }^{-1} \\
+ \text { Sulphur } 30 \text { kgha }^{-1}\end{array}$ & 13.90 & 33.08 & 24420 & 63342 & 38922 & 2.59 \\
\hline $\mathbf{T}_{6}$ & $\begin{array}{l}\text { RDF + FYM } 1 \text { tha }^{-1} \\
+ \text { Sulphur } 40 \mathrm{~kg} \mathrm{ha}^{-1}\end{array}$ & 15.83 & 38.42 & 24820 & 72249 & 47429 & 2.91 \\
\hline \multirow[t]{3}{*}{$\mathbf{T}_{7}$} & $\begin{array}{l}\text { RDF + FYM } 1 \text { tha }^{-1} \\
+ \text { Sulphur } 50 \text { kgha }^{-1}\end{array}$ & 14.31 & 34.66 & 25220 & 65301 & 40081 & 2.59 \\
\hline & $\mathrm{SE} \pm$ & 0.31 & 0.91 & -- & -- & -- & -- \\
\hline & $\mathrm{CD}$ at $5 \%$ & 0.89 & 2.63 & -- & -- & -- & -- \\
\hline
\end{tabular}

Rates :Grain : Rs 4200/- $\mathrm{q}^{-1}$, Stover : Rs 150/- $\mathrm{q}^{-1}$, Sulpher @ Rs. $40 / \mathrm{kg}^{-1}$.

FYM seems to act directly in increasing crop yield either by accelerations of respiratory process by increasing cell permeability by hormone growth action or by combination of all the process viz. release of nutrients, increasing the availability of nutrients and improving soil physical, chemical and biological properties (Rasool et al., 2013). Roy and Ghosh (2020) reported that, sulphur play an important role in the formation of glucosides which on hydrolysis produce higher amount of oil and also responsible for sulpha- hydril linkage and activation of enzymes which help in biochemical reactions within the plant help in increasing the oil content. Aziz et al., (2018) reported that, application of FYM (10 t ha $\left.{ }^{-1}\right)$ recorded highest oil content in grain of soybean. This increase may be due to mineralization of organic nutrients of FYM as well as microbial activity due to available organic carbon. The mineralization of organic nutrients enhanced oil content due to synthesis of fatty acids and their etherification by accelerating biochemical reaction in glycoxalate cycle.

\section{Nutrient uptake}

The pooled data regarding nutrient uptake are presented in Table 3. From the pooled data, it was revealed that, the treatment $\mathrm{T}_{6}$ i.e. NPK 50:25:00 kg ha ${ }^{-1}+$ FYM 1 tha $^{-1}$ with sulphur $40 \mathrm{~kg} \mathrm{ha}^{-1}$ recorded significantly higher uptake of $\mathrm{N}, \mathrm{P}$ and $\mathrm{K}(44.76,17.37$ and $100.15 \mathrm{~kg}$ ha ${ }^{1}$ ) over rest of the treatments.

\section{Soil analysis at harvest}

The treatment wise soil samples were collected after harvest and analyzed for 
different parameters and are presented in Table 4. From the pooled data, it was seen that, the soil $\mathrm{pH}, \mathrm{EC}$, and the organic carbon content was found non-significant except the sulphur content (ppm) due to different treatments. The treatment $\mathrm{T}_{7}$ i.e. i.e. NPK 50:25:00 kg ha ${ }^{-1}+$ FYM 1 tha $^{-1}$ with sulphur $50 \mathrm{~kg} \mathrm{ha}^{-1}$ recorded higher sulphur content $(9.62 \mathrm{ppm})$ over rest of the treatments. However, it was on par with the treatment $\mathrm{T}_{6}$.

\section{Available Nutrients}

The pooled data regarding the available nutrients $\left(\mathrm{kg} \mathrm{ha}^{-1}\right)$ was presented in Table 5 . From the data it was revealed that, $\mathrm{T}_{6}$ i.e. NPK 50:25:00 kg ha ${ }^{-1}+$ FYM 1 tha $^{-1}$ with sulphur $40 \mathrm{~kg} \mathrm{ha}^{-1}$ recorded significantly higher available $\mathrm{N}, \mathrm{P}$ and $\mathrm{K}(176.0,15.16$ and 624.0 $\mathrm{kg} \mathrm{ha}^{-1}$ ) followed by the treatment $\mathrm{T}_{7}$. Kumar et al., (2009) reported that, organic manures along with inorganic fertilizers attribute to higher availability and adsorption of nutrients. FYM is a store house of several macro and micronutrients which are released during the process of mineralization and stimulated the activity of microorganism that make the plant nutrients readily available to the crop (Rasool et al., 2013).

\section{Economics}

The pooled data pertaining to economics are reported in Table 6 . From this table it was revealed that, the highest pooled grain and stover yield (15.83 and $38.42 \mathrm{q} \mathrm{ha}^{-1}$ ) with higher gross monitory returns, net returns and cost benefit ratio (Rs.72249/-,Rs.47429/- and 2.91 respectively) was observed in treatment $\mathrm{T}_{6}$ i.e. NPK 50:25:00 $\mathrm{kg} \mathrm{ha}^{-1}+$ FYM 1 tha $^{-1}$ with sulphur $40 \mathrm{~kg} \mathrm{ha}^{-1}$ over rest of the treatments.

Based on the foregoing results, it can be concluded that, significantly higher grain and stover yield and its components as well as nutrient uptake and available nutrients in the soil were obtained with the plants supplied with recommended dose of NPK 50:25:00 kg $\mathrm{ha}^{-1}+$ FYM 1 tha $^{-1}$ with sulphur $40 \mathrm{~kg} \mathrm{ha}^{-1}$ and required more critical testing of such nutrient studies at multiplications.

\section{Acknowledgement}

Authors are thankful to the Chief Scientist \& A.D.R., Research Scientists and staff members of Z.A.R.S. Solapur for conducting the experiment at the center.

\section{References}

Aziz, M. A., Narinder P., Thamina, M., Tahir, M. and Tajamul, I. 2018. Farm yard manure and dalweed improve the growth and yield in soybean (Glycine $\max$ L.) Merill. J. Pharmacognosy and Phytochemistry. 7(2): $1532: 1537$.

Rasool, F., Hasan, B., Aalum, I. and Gaine, S. A. 2013. Effect of nitrogen, sulphur and farmyard manure on growth dynamics and yield of sunflower (Helianthus annus L.) under temperate conditions. Scientific Research and Essays 8(43), 2144-2147.

Gaikwad, S. S. and Puranik, R. B. 1996. Effect of pressmud cake (PMC) and fertilizer on the yield and uptake of secondary nutrients by soybean (Glycine $\max$ L.) in entisol. J. Soils and Crops. 6(2) : 190-193.

Jackson, M. L. 1973. Soil chemical analysis. Prentice Hall of India Pvt. Ltd., New Delhi,pp. 134-204.

Kanwar, J. S. and Mudahar, M. S. 1986. Fertilizer Sulphur and Food Production. Martinus Nijhoff/ Dr W. Junk Publisher, Dordrecht 247p.

Knudsen, D. and Peterson, G. A. 1982. Lithium, sodium and potassium. $\mathrm{p}$ 225-246. In A. L. Page (Ed.) Methods of soil analysis, Agronomy monogram No. 9, Am. Soc. Agron. Inc., Soil Sci. Soc. Am. Inc. Publisher, Madison, Wisconsin, USA.

Kumar, R. P., Singh, O. N., Singh, Y., Dwivedi, S. and Singh, J. P. 2009. Effect of integrated nutrient management on growth, yield, 
nutrient uptake and economics of French bean (Phaseolus vulgaris). Ind. J. Agril. Sci. 79 (2) : 122-128.

McLean, E. O. 1982. Soil $\mathrm{p} \mathrm{H}$ and lime requirement. In Page, A L, R H Miller and D R Keeeney (eds.) Methods of soil analysis. Part 2- Chemical and microbiological properties. $\left(2^{\text {nd }}\right.$ Ed.) Agronomy, 9: 199-233.

Nagaraj, G. 1993. Safflower seed composition and oil quality- A review. In Proceeding of the $3^{\text {rd }}$ International safflower Conference, Beijing, 58-71.

Najar, G. R., Singh, S. R., Akthar, F. and Hakeem, S. A. 2011. Influence of sulphur levels on yield, uptake and quality of soyabean (Glycine max) under temprate conditions of Kashmir valley. Ind. J. Agric. Sci. 81 (4) : 340-343.

Olsen, S. R., Cole, C. L., Watanabe, F. S. and Dean, D. A. 1954. Estimation of available phosphorus in soil by extraction with sodium bicarbonate, USDA Cir. No. 939.

Roy, N. and Ghosh, G. 2020. Enhancing nutrient availability, yield and quality of safflower (Carthamus tinctonius L.) through zink and sulphur in Aifisol. J. Pharmacognosy and Phytochemistry. 9(1) : 693-697.

Panse, V. G. and Sukhatme, P. V. 1985. "Statistical methods for agricultural workers". ICAR, New Delhi.

Rahamatalla, A. B., Babiker, E. E., Krishna, A. G. and El. Tinay, A. H. 2001. Change in fatty acid composition during seed growth and physiochemical characteristics of oil extracted from four safflower cultivars. Plant Foods for Human Nutrition, 56 : 385-395.

Rhoades, J. D. 1982. Soluble salts. In "Methods of soil analysis, Part 2, chemical and microbiological properties" (AL Page, RH Miller, DR Keeney eds.) pp. 635-655.
(Agron. Mono. 9, ASA and SSSA: Madison, Wisconsin).

Shivakumar, B. G. and Ahlawat, I. P. S. 2008. Integrated nutrient management in soybean (Glycine max) - wheat (Triticum aestivum) cropping system. Ind. J. Agronomy. 53 (4) : 273-278.

Singh, R., Bhumbla, D. R. and Keefer, R. K. 1988. Recommended soil sulphate $-\mathrm{S}$ test. pp.41-46. In Agric. Expt. Stn. Univ. of Delaware, Newark, 1999. Soil testing procedures for the north -eastern U.S. Bulletin. No. 493.p.42-46.

Singh, V., Galande, M. K., Deshpande, M. B. and Nimbkar, N. 2001. Inheritance of wilt (Fusarium oxysporum f. sp. carthami) resistance in safflower. In proceedings of the $5^{\text {th }}$ International Safflower Conference, Williston, ND, and Sidney, MT, July 2327.

Subbaiah, B. V. and Asija, G. L. 1956. A rapid procedure for determination of available nitrogen in soil. Current Science, 25: 259260.

Thirumelai, M. and Khalak, A. 1993. Fertilizer application economics in French bean. Current Research University of Agricultural Sciences, Bangalore. 22 (3.5) : 67-69.

Tiwari, P. N., Gambhir, P. N. and Rajan, T. S. 1974. Rapid and non destructive determination of oil in oilseeds by pulsed N.M.R. technique. J. American Oil Chemical Society, II.51:104-109.

Walia, N., Kaur, A. and Babbar, S. B. 2005. In vitro regeneration of a high oil yielding variety of safflower (Carthamus tinctorius var. HUS - 305). J. Plant Biochemistry and Biotechnology. $14: 1-4$.

Walkley, A. J. and Black, C. A. 1934. Estimation of organic carbon by chromic acid titration method. Soil Sci., 37 : 29-38.

\section{How to cite this article:}

Bhite, B. R., B. S. Kadam, T. S. Bhondve, R. M. Gethe, L. N. Tagad and Amrutsagar, V. M. 2021. Effect of Sulphur Levels and FYM on Yield, Oil Content and Nutrient Uptake of Safflower under Dry Land Agriculture. Int.J.Curr.Microbiol.App.Sci. 10(08): 312-319. doi: https://doi.org/10.20546/ijcmas.2021.1008.036 